\title{
KÜLÖNLEGES MŰVELETI KÖTELÉKEK ABV TÁMOGATÁSI LEHETŐSÉGEI
}

\section{CBRN SUPPORT POSSIBILITIES OF SPECIAL OPERATION FORCES}

\author{
CSÓKA Attila \\ (ORCID: 0000-0001-9873-0789) \\ csoka.attila@yahoo.com
}

\begin{abstract}
Absztrakt
A különleges müveleti kötelékek fejlesztése, alkalmazása iránti igény a védelmi felülvizsgálat során kialakuló válaszlépés a változó biztonsági környezetre. A fejlődő különleges müveleti kötelékek egyik feladata a részvétel a tömegpusztító fegyverek elterjedése elleni harcban, így az ebben részt vevő katonák, alegységek, egységek $A B V$ támogatása elengedhetetlen. Jelen tanulmány dandár szintig tárgyalja az $A B V$ támogatás lehetőségeit.
\end{abstract}

Kulcsszavak: $A B V$ támogatás, CBRN MERT, Különleges müveletek

\begin{abstract}
The need of the development and application of special operation forces is a response to the changing security environment during the security review. One of the activities of the developing special operation forces is countering proliferation of weapons of mass destruction thus the CBRN support of participating troops, subunits and units is indispensable The study discusses the possibilities of CBRN support up to brigade level.
\end{abstract}

Keywords: CBRN support, CBRN MERT, Special Operations 
„Ha valaki azt mondhatja magáról: felebaráti szeretetemben, jó cselekedeteimben, hazám iránti hüségemben, méltányosságra és igazságosságra irányuló törekvésemben nem változtam soha, és soha nem is fogok megváltozni, akkor nem szólok semmit; és boldog, aki ezt önmagáról igazán elmondhatja! De egyebekben, mint pl. a politikában, az orvostudományban, a gazdaságtanban stb. stb. változatlansággal kérkedni: merő ostobaság."

Széchenyi István

\section{BEVEZETÉS}

A 2001. szeptember 11-én, az Amerikai Egyesült Államok ellen öngyilkos merénylők által végrehajtott terrorista támadások ${ }^{1}$ nem csak a világ közvéleményére, az USA külpolitikájára, a terrorizmus elleni harc meghirdetésére volt hatással. Nagyobb figyelmet kapott az Észak-atlanti Szerződés Szervezetében a kis létszámú erők képességeinek kialakítása, azok kiaknázása, alkalmazása. Ezzel párhuzamosan, a 2003-ban végrehajtott védelmi felülvizsgálat következtében 2005-től Magyarországon is megkezdődött a különleges müveleti képesség kialakítása. A fejlesztés az MH 34. Bercsényi László Felderítő Zászlóalj név-, és szervezeti változásával kezdődött meg, amikor 2005. szeptember 01-én az MH 34. Bercsényi László Különleges Mủveleti Zászlóalj nevet vette fel az alapító okirat módosításával. [1]

Jelenleg a Magyar Honvédség Hadrendjében MH 2. vitéz Bertalan Árpád Különleges Rendeltetésü Dandár készül a feladataira, illetve távlati terv a magyar vezetés alatt álló többnemzeti regionális különleges müveleti parancsnokság kialakítása.

A különleges müveletek ABV támogatása lehetőségeinek vizsgálata lényeges feladat, ugyanis a különleges műveleti kötelékek ABV támogatása a különleges müveletek és az ABV védelmi feladatok határán lévő, mindkét szakterület alapos ismeretét megkövetelő kihívás.

\section{KÜLÖNLEGES MÜVELETI ERÖKKEL SZEMBEN TÁMASZTOTT ABV VÉDELMI KÖVETELMÉNYEK}

$\mathrm{Az} A B V$ védelem több irányból is megközelítve szerves része a különleges műveleti erők alkalmazásának.

1. Az egyéni és kollektív ABV védelem követelmény minden csapattal szemben. Minden katonai szervezetnek - a szakosodása figyelembe vétele nélkül - biztosítania kell a katonái túlélőképességét az egyéni és kollektív ABV védelmi védőeszközök, az ABV felderítő-, és mentesítő eszközök biztosításával, az azokra való kiképzéssel. Az ABV védelem eszközei, különösen az egyéni és kollektív védelem és az egészségügyi intézkedések szükségesek ugyanis annak érdekében, hogy a személyi állomány a csapást túlélje és képes legyen feladatait $A B V$ környezetben folytatni. Bármely katonai mủveleti tevékenység ABV védelme akkor hatékony, ha a részvevők a legbonyolultabb $\mathrm{ABV}$ helyzetben is képesek saját túlélésüket biztosítani. [2] Az ABV védelem megjelenik már az alapkiképzés tematikájában, illetve az Általános Katonai Kiképzés Kézikönyve is mintegy 100 oldalon át tárgyalja a vegyivédelmi támogatás témakörét.

\footnotetext{
${ }^{1}$ Szélsőséges terroristák eltérítettek négy utasszállító repülőgépet, amelyet jelképes amerikai épületekbe vezettek: kettő a New York-i világkereskedelmi központ épületébe, egy a Pentagon épületébe csapódott, a negyediket az utasok visszafoglalták, de nem tudták megakadályozni a lezuhanását. A terrorakció során több mint 3000 ember veszítette el az életét.
} 
2. A különleges mủveleti szabályzók $A B V$ védelemmel kapcsolatos feladatokat szabnak meg az alábbiaknak megfelelően:

A különleges müveletek meghatározása a különleges müveleti doktrína alapján [3]:

A különleges müveletek olyan katonai tevékenységek, amelyeket struktúrájában erre a célra kialakított, szervezett, speciálisan kiképzett és felszerelt, kis létszámú katonai egységek hajtanak végre a hagyományos fegyveres erők által többnyire nem alkalmazott harceljárások és alkalmazási módok felhasználásával. Ezen tevékenységeket a katonai müveletek teljes spektrumában (békemüveletek, válsághelyzet, minősített időszak) a stratégiai vagy hadmüveleti célkitüzések elérése érdekében önállóan, vagy a hagyományos fegyveres erők többi haderőnemével együttmüködésben hajtják végre. A politikai-katonai célkitüzéseknek megfelelöen ezen feladatok végrehajthatóak nyíltan, rejtetten, illetve fedetten.

A különleges müveletek elsődleges feladatai [4]:

- Katonai segítségnyújtás (kiképzés, tanácsadás, mentorálás);

- Különleges felderítés (magában foglalja a környezet felderítését, fenyegetettség értékelést, célpont értékelést, csapás utáni értékelést);

- Közvetlen müveletek.

A fenti feladatok az MH különleges müveleti doktrína alapján kiegészítésre kerültek a nem hagyományos hadviseléssel.

Egyéb támogató feladatok [3]:

- Részvétel a terrorizmus elleni harc katonai feladataiban;

- Katasztrófavédelmi feladatokban való részvétel és humanitárius segítségnyújtás;

- Béke és háborús kutató-mentő feladatokban való részvétel;

- Információs müveletek támogatása;

- Kiemelten fontos személyek, nemzeti ereklyék, illetve objektumok biztosítása és védelme. (A feladat fizikai végrehajtási képessége terén, nem pedig jogi képesség értelmében);

- Túszmentés végrehajtása hadmüveleti területen. (A megfelelő jogi környezet megteremtését követöen lehetséges.);

- Részvétel a tömegpusztító és hagyományos fegyverek elterjedése elleni harc katonai feladataiban;

- Részvétel a bűnszervezetek elleni harc katonai feladataiban. (A megfelelő jogi környezet megteremtését követően, hadmüveleti területen lehetséges.)

Ahogy azt a különleges műveleti doktrína is alátámasztja, az erők megóvásának keretén belül megvalósuló $\mathrm{ABV}$ védelmi követelmények teljesítése nem elégséges egy különleges müveleti alegység/egység támogatásának tervezésekor, az ABV környezetben való alaprendeltetés szerinti feladatok végrehajtását is biztosítani szükséges.

3. A Különleges Müveleti Komponens Parancsnokság kézikönyve [5] részletezi az ABV védelmi fenyegetettséghez kapcsolódó különleges műveleti feladatokat. A fö feladat a tömegpusztító fegyverek elterjedése elleni tevékenység, amelynek keretében fel kell készülni az alábbiakra:

- ABV detektálás, azonosítás, figyelés;

- Információ menedzsment;

- Fizikai védelem;

- Veszély kezelés. 
A terület integritását mutatja, hogy a fenti pontok (az egészségügyi ellenrendszabályok és egészségügyi támogatással kiegészítve) megegyeznek az MH ÖHP által kiadott Atom, Biológiai, Vegyi védelmi doktrínában [6] megfogalmazott $A B V$ védelmi feladatokkal.

4. A NATO képességkódjai, az általános, erők megóvása keretén belül megvalósuló feladatokon túl meghatározzák az alábbi, ABV vonatkozású követelményeket:

Egy általános dandár esetén:

- Képes speciális ABV támogatást biztosítani az alárendelt szervezeti elemeinek.

- A fenti követelmény egy könnyü dandár esetén:

- Képes müveleteket végrehajtani ABV környezetben.

Egy különleges műveleti osztag esetén:

- A létfontosságú vezetési elemek védelmével képes megőrizni a teljes müveleti képességet $\mathrm{ABV}$ környezetben, továbbá szinten tartja a hatékony $\mathrm{C} \mathrm{ISR}^{2}$ képességet a müveletek fenntartásához ABV eseményt követően.

\section{AZ ABV VÉDELEM FELADATAI}

A különleges müveleti erőkkel szemben támasztott $A B V$ védelmi követelményeket párhuzamban kell áttekinteni az $\mathrm{ABV}$ védelem feladatainak teljesülési lehetőségeivel. $\mathrm{Az} A \mathrm{AB}$ védelem feladatai az alábbiak [6]:

- ABV felderítés és ellenőrzés;

- ABV Riasztás és Értesítés;

- Egészségügyi ellenrendszabályok és egészségügyi támogatás;

- Fizikai védelem;

- Veszélyek kezelése.

\section{ABV felderítés és ellenőrzés}

Magában foglalja az ABV ellenőrzést, sugáradag ellenőrzést, ABV felderítést - ideértve az azonosítást és detektálást.

A harcászati szintü katonai szervezetek tevékenységének irányt szab az elöljáró katonai szervezet által évente kiadott Kiképzési Intézkedés, amely a fö kiképzési feladatok/rendezvények mellett meghatározza század szinten 3 fö nem szervezetszerü ABV felderítő katona felkészítését, továbbá századonként egy megbízott ABV védelmi altiszt kiképzését.

A különleges müveleti erők esetében a fentiek megvalósíthatóságát vizsgálva az első tényező a századszintű szervezeti elem hiánya a végrehajtó alegységeknél. Megfontolva az osztagok létszámát, valamint a csoportok alkalmazási módját, arra a következtetésre lehet jutni, hogy osztagonként kerüljön kijelölésre és felkészítésre a 3 fö nem szervezetszerü ABV felderítő katona, akik összekovácsolva egy nem szervezetszerü $A B V$ felderítő rajt képeznek. A századszintü logisztikai alegység az alapszabályzónak megfelelően készíti fel a nem szervezetszerü $\mathrm{ABV}$ felderítő rajt.

A sugáradag ellenőrzéshez egyéni doziméterek alkalmazása szükséges. Egy megfontolandó lehetőség a SOR/T minősített elektronikus doziméter, amely harcászati (gamma és neutron) és a visszamaradó/háttér gamma sugárzás okozta sugáradag mérésére alkalmas. A különleges müveletek során felmerülö környezeti hatásoknak ellenáll: müködési tartománya megfelelő

\footnotetext{
${ }^{2}$ Command, control, communication, computers, intelligence, surveillance, reconnaissance. Vezetés, irányítás, kommunkikáció, számitógépek, hírszerzés, megfigyelés, felderítés.
} 
elemmel $-40{ }^{\circ} \mathrm{C}$ és $+50{ }^{\circ} \mathrm{C}$ közötti, ellenáll az elektromágneses impulzusok hatásainak, víz-, és vibrációálló. Kicsi, könnyü, mindösszesen $55 \mathrm{~g}$ a súlya, hordható nyakban, övre csíptetve, karra erősítve. Ruha alatt viselve kezelöi tevékenység nélkül adattovábbítására képes a kiértékelő müszerrel. 4 riasztás beállítására ad lehetőséget: 2 beállított sugárszint illetve 2 beállított sugáradag esetén riaszthat.

Ez utóbbinak átgondolva a gyakorlati jelentőségét: részletes ABV védelmi szaktechnikai és szakharcászati kiképzés nélkül a különleges müveleti csoportok tagjai képesek észlelni a veszélyes (elöre beállított) gamma és neutron sugárszintet és sugáradagot, kiküszöbölve annak a kockázatát, hogy úgy végeznek ABV környezetben tevékenységet, hogy nincs tudomásuk sugárveszélyről.

Műveletek során szükséges a sugáradag személyenkénti mérése, mivel ez a szennyezett terepszakaszról történő kivonás utáni következő feladat meghatározásának és az esetleges EÜ kezelés szintjének meghatározásának alapja

A SOR/T doziméterek kiértékelése a XOM/T doziméter adatleolvasó/író készülék alkalmazásával történik, amely alkalmas vezeték nélküli adatcserére azokkal. Adatbázisa lehetővé teszi 250 doziméter menedzselését (200 személy +50 csoport), amely alapján meghatározható, valamint az alkalmazás elveit figyelembe véve javasolt különleges müveleti osztagonként minimum egy XOM/T számvetése.

Hagyományos műveletek végrehajtása során a sugáradagmérők kiértékelése és nyilvántartása az egészségügyi támogató személyzet feladata ${ }^{3}$, azonban az $\mathrm{ABV}$ védelmi törzstiszt/ $A B V$ védelmi altiszt részére információt kell arról szolgáltatnia - a személy feladatra történő bevethetösége illetve az engedélyezett sugáradag, valamint az ebből számított visszafordulási sugáradag ${ }^{4}$ meghatározása érdekében.

Különleges müveletek során a sugáradagmérők kiértékeléséhez az optimális megoldás több változó tényező függvénye, amelyeket figyelembe kell venni, és már a tervezés során be kell vonni az $\mathrm{ABV}$ védelmi és egészségügyi szakértőket. A tervezés alaptényezői az alábbiak:

- A támogatott kötelék törzs-, és támogató elemeinek elhelyezkedése, a kialakult hadmüveleti helyzet;

- A bevont különleges müveleti erők száma, szintje;

- A különleges müveleti erők szakmai irányítása (különleges müveleti osztag került bevonásra, vagy azok önállóan müködnek a támogatott kötelék különleges müveleti törzselemének szakmai irányításával)

- A végrehajtandó feladat.

\section{ABV Riasztás és Értesítés}

A személyi állomány riasztásán túl idetartozik az ABV Riasztási és Értesítési Rendszer ${ }^{5}$ müködtetése.

A személyi állomány riasztását egy katonai szervezeten belül a hagyományos riasztási és értesítési rendnek megfelelően hajtják végre. Annak érdekében, hogy a katonai szervezet

\footnotetext{
${ }^{3}$ A XOM/T készülék kezelése nem követeli meg részletes szaktechnikai kiképzés meglétét, azonban szükség esetén a egészségügyi állomány a vizsgálatokat, kezeléseket azonnal meg tudja kezdeni. Az egészségügyi személyzet általi kiértékelést alátámasztja az, hogy a sugárterhelés különböző biológiai hatást fejthet ki annak függvényében, hogy milyen az elnyelő szövettől. Ennek jellemzésére az effektív dózisegyenértéket használjuk. ${ }^{4}$ Dóziskorlátokkal célkitüzés az ALARA elv érvényesítése. Minden dózist olyan alacsonyan kell tartani, amennyire csak ésszerüen lehetséges. Egy feladat elrendelésekor az elnyelhető illetve már elnyelt dózist figyelembe véve számítható a visszafordulási sugáradag-a mủvelet végrehajtása során megengedett sugáradag fele. Lehetőséget ad az eszköz arra, hogy ennek elérését riasztással jelezze az alkalmazónak.

${ }^{5}$ MH ABV RIÉR
} 
tájékoztatást kapjon egy riasztás alapjául szolgáló eseményről, azok áramlására az ABV RIÉRen keresztül kerül sor.

Az ABV RIÉR célja a vegyi-, sugár-, és biológiai helyzet gyors felmérése, a parancsnokok támogatása, a döntések szakmai megalapozása továbbá a veszélyeztetett szervezetek azonnali riasztása, ezzel a csapatok veszteségeinek csökkentése, harc- és túlélőképességének biztosítása, valamint a kockázati tényezők minimalizálása.

A nem szervezetszerű $\mathrm{ABV}$ felderítő rajok biztosítják a forrásszintű adatokat az $\mathrm{ABV}$ Riasztási és Értesítési Rendszer müködéséhez. Ahogy korábban említésre került, a nem szervezetszerü ABV felderítő rajokkal szemben nem követelmény az aktuális ATP 45 szerint CBRN jelentések elkészítése, csupán az azok elkészítéséhez szükséges alapadatok biztosítása, megkötés nélküli formátumban. Osztag szinten-tekintettel azok létszámára, alkalmazási lehetőségeire, ABV RIÉR értékelő csoport biztosítására nem megkövetelt. A század megbízott ABV védelmi altiszt megnevezést módosítva - tekintettel a különleges müveleti erők megnevezésére- az osztag megbízott $A B V$ védelmi altiszt feladata a nem szervezetszerü $A B V$ felderítő rajok által jelentett információk alapján az érvényben levő ATP 45 szabályzat szerinti CBRN 1 illetve 4 jelentések elkészítése és a dandár szinten müködő ABV RIÉR alközpont, vagy a támogatott vezetési elemnél müködő adatgyüjtő és értékelő szervezeti elem részére.

\section{Egészségügyi ellenrendszabályok és egészségügyi támogatás}

Ebbe a feladatkörbe tartozik a megelőző egészségügyi kezelés, a sérültek kezelése ABV környezetben, az egészségügyi ellenrendszabályok illetve a kiürítés.

A megelőző egészségügyi kezelés a sérültek kezelése, az egészségügyi ellenrendszabályok jellemzően az egészségügyi támogatás feladatkörébe tartoznak. Az ABV védelem érintettsége sebesült mentesítésére alkalmas ABV mentesítő helyek, illetve a sérültek kezelése érdekében kollektív védelmet biztosító berendezések telepítése kapcsán jelenik meg.

A kiürítés elrendelése hadmüveleti feladat. A kollektív védelemmel nem rendelkező állomány esetében a harcászati/hadmüveleti célok fontosságát kell a felvállalt kockázattal összehasonlítani és ez alapján meghozni a döntést.

Kollektív védelemmel rendelkező állomány esetén a harcászati/hadműveleti érdekeken túlmenően - különösen sugárszennyezés esetén - több összetevőt kell vizsgálni. Számításba kell venni a kollektív védelem ellenére az állományt érő hatásokat, figyelembe kell venni az idő múlásával a káros hatás csökkenését, valamint a kollektív védelem nélkül a kiürítés közben állományt érő hatásokat, a kiürítés idejét - azaz amíg az előző hatásnak ki vannak téve a katonák. Az előzőek alapján ki lehet számítani az ideális időpontot, amikor a kiürítés során a lehető legkevesebb káros hatás éri az állományt.

Belátható, hogy a parancsnok elé terjesztett döntési javaslat elökészítése olyan ismereteket igényel, és olyan felelősséggel jár, amit nem lehet egy rövid tanfolyam során elsajátítani és éppen ezért felelösen nem lehet az ABV védelem feladatkörében csekély tapasztalattal bíró, megbízott személyre bízni.

\section{Fizikai védelem}

Magában foglalja az egyéni és kollektív védelmet, továbbá az egyén túlélőképességét.

Az egyéni védelem illetve a túlélőképesség az eszközökkel való ellátottság vonatkozásában - beleértve az egyéni védőeszközöket, a CALID kimutató papírt, a dozimétereket, az egyéni ABV mentesítő csomagokat, a 2 tonnánál nehezebb gépjárművekhez rendszeresített mentesítő készletet - logisztikai, az eszközök alkalmazásának készsége vizsgálatában kiképzési, a fenyegetettség függvényében a védőeszközök alkalmazási szintjének meghatározása hadmüveleti kérdés. Az egyéni és kollektív védőeszközök védelmi szintjének alkalmazási körzeten belül történő meghatározásának alapja az $\mathrm{ABV}$ felmérésen alapuló $\mathrm{ABV}$ fenyegetettség értékelési folyamat. 
A fenyegetettség értékelés, a felderítő jelentések, az ipari létesítmények, a korábbi ABV események elemzése a parancsnok hasonlóan szaktiszt igényként merül fel a dandártörzsben. A lövész alakulatoknál századszintig alkalmazott Troop Leading Procedures helyett a különleges müveleti erők osztag szinten és alatta is a Military Decision Making Process-t alkalmazzák, így az osztagok tervezési munkája során a megbízott $\mathrm{ABV}$ védelmi altiszt törzstámogató munkája szükséges.

\section{Veszélyek kezelése}

Magában foglalja a szennyezés elkerülését, az ABV mentesítést illetve az ABV szennyezés szétterjedésének megakadályozását.

A szennyezés elkerülése feltételezi a szennyezett terület határainak az ismeretét. Amennyiben az erre vonatkozó információ már ismert, azt az ABV RIÉR-en keresztül megkapja a dandár ABV RIÉR alközpont, ami alapján a dandár törzstiszt intézkedik, hogy az alárendelt osztagok szolgálati úton tájékoztatásra kerüljenek. Amennyiben az osztagparancsnok, vagy az alárendelt csoportok részéről kérdések merülnek fel, azokat az osztag megbízott ABV védelmi altiszt válaszolja meg, vagy szakmai úton a kérdéseket továbbítja a dandár $A B V$ védelmi törzstiszt felé. A szennyezés elkerülése valamint a harcászati/hadmüveleti/stratégiai érdek ütközése esetén szintén mérlegelésre kerül sor, azonban ennek a felelőssége már nem a dandár $A B V$ szakállományát terheli. A fentieken túl a szennyezés elkerülése magában foglalja a megjelölést (ABV felmérést), az útvonaltervezést illetve az áttelepülést is.

A szétterjedés megakadályozása során a szennyezett eszközök, állomány mozgásának behatárolt területre történő korlátozását ${ }^{6}$, a nem szennyezett állomány eszközök korlátozását a tiszta területre, a szennyeződés elszigetelését, valamint a szennyezett hulladékkezelést értjük.

Amennyiben a szennyezés már nem elkerülhető, akkor szükséges az ABV mentesítés.

Az ABV mentesítés olyan fizikai, fizikai-kémiai, kémiai folyamat, mely a szennyező anyag eltávolítását, megsemmisítését jelenti.

Az ABV mentesítést típusa alapján feloszthatjuk [6]:

Azonnali, vagy önmentesítés:

Az egyén által a szennyeződés bekövetkezését követően az élet megóvása és a veszteségek minimalizálása érdekében végrehajtott mentesítés. Magában foglalhatja bizonyos személyi ruházati anyag és/vagy más személyi felszerelési tárgy bizonyos részeinek mentesítését. Végrehajtható a rendszeresített Egyéni Mentesítő Csomaggal.

Részleges mentesítés:

A harcfeladat folytatása, a veszély csökkentése, a szennyeződés szétterjedésének megakadályozása érdekében végrehajtott, az alapvető harceszközökre, anyagokra és a tevékenységi körzet legfontosabb részeire korlátozódó mentesítés. A részleges mentesítést a katona, vagy az alegység hajtja végre. A részleges mentesítés magában foglalhatja az egyénnek az önmentesítést meghaladó mentesítését éppen úgy, mint a feladat szempontjából fontos eszközök, tartalékkészletek mentesítését és korlátozott terepmentesítést is. Hazai szabályzók alapján végrehajtható a 2 tonna feletti gépjármüveknél rendszeresített mentesítő készlettel.

\footnotetext{
${ }^{6} \mathrm{Az}$ ABV mentesítés alapelvei: a lehető leghamarabb kerüljön végrehajtásra, csak azt kell mentesíteni, amit szükséges, prioritás, hogy a mentesítés sorrendje a hadmüveleti célokkal megegyezzen, illetve a 4 . alapelv a szennyezettség szétterjedésének megakadályozása érdekében az ABV mentesítés a szennyeződés helyéhez legközelebb kerüljön betervezésre.
} 
Teljes mentesítés:

Szervezetszerü, vagy támogató mentesítő szakalegységekkel végrehajtott mentesítés, melynek célja az állomány, a technikai eszközök, felszerelések és a fegyverzet szennyezettségének csökkentése olyan szintig, amely lehetővé teszi az egyéni védőeszközök teljes, vagy részleges levetését és biztosítja a feladat végrehajtását minimális mértékü harc- és munkavégző képesség csökkenéssel. Ez magába foglalhatja a terep mentesítését is. Végrehajtható a támogatott szervezeti elem alárendeltségében lévő szakalegységgel, vagy egy modul rendszerü $\mathrm{ABV}$ támogatási feladatokra is képes alegységgel.

\section{ABV TÁMOGATÓ ERŐK}

\section{Nem szervezetszerü $A B V$ felderítő rajok}

A nem szervezetszerü ABV felderítő katonák legfontosabb feladata az ABV felderítő eljárások és az ABV felmérés alapvető ismerete. Ismerniük kell a tevékenység rendjét útvonal felderítése, terület, zóna felderítése, objektum, körlet monitorozása, ABV figyelése, illetve már ismert szennyezet terület határainak meghatározása során. Képesnek kell lenniük a rendszeresített vegyi-, és sugárfelderítő eszközeik alkalmazására, azok technikai kiszolgálására. Ismerniük kell az ABV védelmi jeleket és jelzéseket. Tudniuk kell, hogy milyen információk szolgáltatása szükséges egy ABV esemény illetve szakfeladat kapcsán az ABV RIÉR müködtetéséhez, a CBRN jelentések tartalommal való feltöltéséhez, mindemellett az ABV RIÉR CBRN jelentéseinek felépítését nem szükséges elsajátítaniuk.

A nem szervezetszerü ABV felderítő rajok jelenleg alkalmazott eszközei a CAM vegyi jelző, illetve az IH-95 sugárszint-, és szennyezettség mérő müszer. Tekintettel arra, hogy mindkét eszköz az előző században került fejlesztésre, a CAM mérete és képességei ${ }^{7}$, valamint az IH 95-ös ergonomitása is lehetőséget ad a fejlődésre, ami külön vizsgálat tárgya lehet a különleges müveleti alegységek ellátásakor. A csapatoknál rendszeresített vegyifelderítő eszközök vizsgálatával foglalkozó korábbi kutatások (Berek 2016) is feltárták már a vegyifelderítés kihívásait és megállapították e terület technikai fejlesztési irányait különösen a fenti szempontok figyelembe vételével. [7]

Különleges müveleti osztagonként a nem szervezetszerü $A B V$ felderítő rajok kijelölése során figyelembe kell venni azt, hogy az ABV felderítés osztagonként mindösszesen néhány személy jelentette képesség. Amennyiben ezek a katonák harcképtelenné válnak, a képesség megszünik. A képesség megőrzése érdekében -amennyiben a kijelölésre a különleges müveleti csoportok állományából kerül sor - csak különösen indokolt esetben javasolt bevonni a felkészített erőket nem ABV jellegü müveletre, ez viszont az adott csoport alkalmazhatóságát korlátozza. Megoldásként javasolt a csoportokat követö, vagy bizonyos esetekben azokkal együtt mozgó Felderítést Támogató Csoport állományából kijelölni és felkészíteni az ABV feladatokra kijelölt másodlagosan felkészített rajt.

A harctámogató osztag mozgástámogató alegységének állományában szolgáló katonák többek között képviselik a müszaki szakterületet is, így az ABV katonák kijelölését is ebböl az alegységből javasolt megtenni.

A logisztikai alegység, mint századszintű szervezet biztosít egy nem szervezetszerü ABV felderítő rajt.

A fenti kijelölt alegységek az erők megóvása érdekében tevékenykednek, a különleges müveleti feladatokkal összefüggő, adott esetben nemzetközi bíróságon is felhasználható ABV

\footnotetext{
${ }^{7}$ Például az LCD 3.3 jelentősen kisebb méretben, a CAM vegyijelzővel szemben üzemmód váltás nélkül képes
} detektálni a hólyaghúzó és idegméreg típusú harcanyagokat, továbbá képes veszélyes ipari anyagok kimutatására. 
védelmi szaktevékenység által szolgáltatott bizonyítékok biztosítására nem alkalmasak, ahhoz külön szakalegység, külön felkészítés és eszközök szükségesek.

\section{Osztag/század megbízott $A B V$ védelmi altisztek}

Az ABV védelmi feladatok végrehajtása érdekében osztagonként/századonként egy fö megbízott $A B V$ védelmi altiszt tevékenysége szükséges, aki a felkészítését követően az alábbi $A B V$ védelmi szakfeladatok végrehajtására kell, hogy képes legyen:

- Ismer minden olyan szaktevékenységet, amely megjelenik a felderítő rajokkal szemben támasztott követelményeknél, továbbá tisztában van az általános $\mathrm{ABV}$ védelmi szabályzók változásával, valamint az $\mathrm{ABV}$ támogató alegységek szaktevékenységét befolyásoló szabályzók változásával;

- Kijelöli, felkészíti a nem szervezetszerü ABV felderítő katonákat, intézkedik összekovácsolásukra nem szervezetszerü $\mathrm{ABV}$ felderítő rajokká;

- Szinten tartani a nem szervezetszerü ABV felderítő rajok ismereteit az ABV védelmi kiképzés keretében;

- Műveletek tervezése során az elöljáró parancsában foglalt, vagy kikövetkeztetett ABV védelemmel kapcsolatos feladatokat és információkat feldolgozza, javaslatot tesz azok megvalósítására;

- Javaslatot tesz a rendelkezésre álló nem szervezetszerü ABV védelmi raj alkalmazására az osztag/századparancsnok felé;

- Az osztag/századparancsnok tanácsadójaként tevékenykedik az osztag/század ABV védelemmel kapcsolatos ügyeiben;

- Felel az ABV Riasztási és Értesítési Rendszer müködtetéséért alegységszinten, képes fogadni az ABV eseményekkel kapcsolatos eseményekről az alárendeltek szöveges jelentéseit, azokat a vonatkozó szabályzóknak megfelelően képes az ABV RIÉR-ben kötött jelentésformátumba átalakítani és továbbítani a katonai szervezet saját alközpontja vagy a támogatott kötelék értékelő szervezeti eleme felé. Képes értelmezni a kapott ABV RIÉR-hez kapcsolódó jelentéseket, azokat képes az alárendelteknek szövegszerüen továbbítani, szükség esetén képes a riasztást végrehajtani;

- Az alárendelt alegységek ABV védelemmel kapcsolatos információigényét megválaszolja, szükség esetén továbbítja a z egység ABV védelmi törzstiszt felé;

- Nyilvántartja a beosztott állomány sugáradag terhelését figyelembe véve az elöljáró sugáradaggal kapcsolatos megkötését, javaslatot tesz azok alkalmazhatóságára, miközben szorosan együttmúködik az egészségügyi állománnyal illetve az egység $A B V$ védelmi törzstiszttel.

Egy osztagon belül az ABV védelmi kiképzésért -legyen az a nem szervezetszerű $A B V$ felderítő rajok kiképzése és összekovácsolása, vagy a teljes személyi állomány ABV védelmi kiképzése- az osztagparancsnok egyetemes felelőssége mellett az osztag megbízott ABV védelmi altiszt szakmai felelőssége is egyben.

\section{$A B V$ védelmi törzstiszt}

Egység szinten az alábbi ABV támogató feladatok végrehajtása és követelmények érvényesítése érdekében felelős kijelölése szükséges. Az ABV védelmi törzstiszt összetett szakfeladatrendszere a részleteiben a következő:

- Ismernie kell az ABV felderítö, ABV mentesítő alapelveket, eljárásokat; 
- Szakmai segítséget nyújt a nem szervezetszerü ABV felderítő rajok összekovácsolásában, ö maga szervezi több raj összekovácsoló felkészítő rendezvényeit;

- Ellenőrzi a század/osztag megbízott ABV védelmi altisztek szakmai tevékenységét;

- ABV fegyverek és/vagy a veszélyes ipari anyagok kockázatát azonosítja a műveleti területen;

- Az egység váratlan eseményekre vonatkozó tervének kidolgozása, mikor ABV fegyverek vagy veszélyes ipari anyag okozta kockázattal szembesül;

- Szükséges esetén javaslatot tesz a parancsnok részére minden ABV fegyver és/vagy veszélyes ipari anyag által okozott kockázatra vonatkozóan;

- Müveletek tervezése során az elöljáró parancsában foglalt, vagy kikövetkeztetett ABV védelemmel kapcsolatos feladatokat és információkat feldolgozza, javaslatot tesz azok megvalósítására;

- Javaslatot tesz a rendelkezésre álló nem szervezetszerü ABV felderítő rajok alkalmazására a parancsnok felé;

- Felel az ABV Riasztási és Értesítési Rendszerért, képes fogadni az ABV eseményekkel kapcsolatos eseményekről az alárendeltek jelentéseit és továbbítani azokat az ABV RIÉR-nek megfelelően. Értelmezi a kapott ABV RIÉR-hez kapcsolódó jelentéseket, azokat képes az alárendelteknek továbbítani, képes a riasztást megszervezni, szükség esetén azt végrehajtani;

- Az alárendelt alegységek ABV védelemmel kapcsolatos információigényét megválaszolja, a megválaszolás érdekében koordinál a törzsben, illetve szükség esetén továbbítja azt az elöljáró szervezet felé;

- Felügyeli a beosztott állomány sugáradag terhelésének nyilvántartását, az alkalmazhatóság érdekében szorosan együttműködik az egészségügyi állománnyal illetve a szakmailag alárendelt század megbízott ABV védelmi altisztekkel;

- Különleges müveletek támogatására kijelölt és alkalmas ABV támogató szakalegység8 felkészítésének, integrálásának megszervezése, alkalmazására vonatkozó javaslattétel a parancsnok felé.

Az ABV RIÉR menedzselése során figyelembe kell venni, hogy az alközpont müködtetése nem egyszemélyes feladat, a törzstiszt jelenléte nem váltja ki a feladatból teljes mértékben az alközpontot megelőzően üzemeltető állományt.

A fenti feladatok maradéktalan és professzionális végrehajtása érdekében ABV támogató törzstiszt tevékenysége szükséges, aki nem csak megfelelő tapasztalattal rendelkezik, hanem a rendfokozata is nyomatékosítja a javaslatait a parancsnok felé, illetve „kikényszeríti” az együttmüködést a törzsben.

\section{Különleges múveletek $A B V$ támogatása szakalegységgel}

A fegyverzet-ellenörzés területén tett erőfeszítések ellenére a tömegpusztító fegyverek elterjedése nem állt meg. Új veszélyforrás az ABV fegyverek gyártásához szükséges anyagok, eszközök, szellemi termékek elterjedéséből adódó fenyegetés. Így ABV eszközök szerepet kaphatnak kisebb helyi háborúkban is. [8]

A fenti mellett nem fegyver fokozatú sugárzó anyagok, mérgező anyagok és biológiai ágensek terrorista szervezetek által történő alkalmazása is veszélyt jelenthet. Különböző toxikus anyagok széles körben elérhetök, és minimális szakértelemre van szükség bünös

\footnotetext{
${ }^{8}$ Lehetőségei részletezve a továbbiakban.
} 
felhasználásukhoz, bár korábban úgy gondolták, hogy azok kijuttatási nehézségei akadályt jelenthetnek az irreguláris csoportok számára. [9]

Tömegpusztító fegyverek és ABV vonatkozású anyagok elterjedése elleni tevékenység céljából tervezett müveletek optimális végrehajtói a különleges müveleti feladatok végrehajtására felkészített és kiképzett $\mathrm{ABV}$ támogató alegységek. Annak ellenére, hogy nem ismertek széleskörüen, a képesség megjelent már az NRF 2016-os váltásában a combined CBRN Joint Task Force keretén belül [10]. A NATO képességkövetelményei között megtalálható a CBRN Multirole Exploitation and Reconnaissance Team ${ }^{9}$. Az alegység képességkövetelményei között szerepel többek között a légi szállítás, a különleges múveleti osztagokkal való együttmüködés és integrálódás, a törvényszéki szintü $A B V$ mintavétel, $A B V$ felderítő feladatok végrehajtása illetve saját maga teljes mentesítése.

Annak érdekében, hogy a különleges müveleti feladatok teljes spektrumát végre lehessen hajtani, egy CBRN MERT jellegü képesség létrehozása szükséges. A képesség kialakításának megkezdésekor az első kérdés az, hogy a felkészítendő állomány milyen elsődleges képzettséggel rendelkezzen. Három verzió lehetséges: ABV védelmi katonák KM felkészítése, KM katonák ABV felkészítése, illetve vegyes összetétel, ahol közösen alkotnak egy alegységet ABV és KM katonák, mindkettőnek felkészítéssel a másik szakterületre.

A megfelelő döntés előkészítéséhez értékelni szükséges az előnyeit és a hátrányait a különböző változatoknak.

\section{Különleges müveleti katonák $A B V$ védelmi felkészítése}

Előnyként jelentkezik, hogy a különleges műveleti feladatok végrehajtása már begyakorolt, a különleges müveletek során összekovácsolt alegység felkészítéséről van szó. Egy helyőrségben települnek a különleges műveleti egységgel, annak állományából kerül kijelölésre, így az integrálódás, a szocializáció nem jelent problémát. A CBRN MERT képesség kialakításakor Lengyelország ezt a változatot követte.

Hátránya az $\mathrm{ABV}$ feladatok nem készségszintü végrehajtása. Vegyenek részt bármilyen ABV felkészítési rendezvényen, az első gondolatból végrehajtott ABV feladatokra nem lesznek képesek.

Hátrányként merül fel, hogy általánosságban a különleges müveleti katonák létszáma az állománytábla lehetőségeihez képest alacsony, így az azokból történő kikülönítés még tovább csökkenti a bevethető KM erők létszámát. Az ABV védelemre felkészített alegység még alkalmas ugyan nem ABV érintett különleges müveletek végrehajtására, azonban az alkalmazhatóságot korlátozza az új képesség: a katonák elvesztését követően a CBRN MERT képesség is elveszik, azaz alkalmazásuk mindenképpen extra kockázattal jár.

További hátrány, hogy a különleges müveleti katonák számára hozzáadott feladat az ABV védelmi tevékenység, tekintettel arra, hogy nem ez a választott szakmai területük egyéni motivációs problémák is felmerülhetnek.

\section{Vegyes összetétel, különleges müveleti és $A B V$ védelmi felkészítéssel}

A változat előnye, hogy mindkét szakma megtalálható az alegységben. Bármilyen feladattal/problémával szembesülnek, lesznek olyan tagjai, akik számára ismert a kihívás és tudják rá az optimális megoldást.

Hátránya az összekovácsolás. Problémát jelenthet a külön szakma, a különböző tapasztalatok, az eltérő szocializálódás. Az állomány kijelölésénél gondot okozhat a különböző szakmában képzett katonák feltehetőleg nem egy helyőrségben élnek, így az integrált alegységnél az ABV katonáknak kellene költözniük, a modul rendszerü alegységnél a KM 
katonáknak, a köztes megoldásnál (csak a kiképzésekre kerülnek összevonásra, egyébként a saját egységének megfelelő békehelyőrségben tevékenykedik) az összekovácsolás gyakorlatilag megvalósíthatatlan. További problémát okozhat a kiképzettség nem egységes szintje. Az elöző változathoz hasonlóan felmerülhetnek motivációs problémák a $\mathrm{KM}$ katonáknál, különösen hangsúlyozottan, ha költözniük is kellene.

\section{$A B V$ védelmi katonák különleges múveleti felkészítése}

Előnye: Összekovácsolt alegység, készségszintű ABV támogatással. Modul elemként szervezve költözés nélkül is egy helyörségben szolgálnak. Maga a lehetőség is ösztönző tényezöként merülhet fel a feltöltöttség tekintetében, hiszen a különleges müveleti egység vonzáskörzetén kívül is vannak olyan katonák, akiket jobban vonz ez a kihívás, mint egy alap vegyivédelmi vagy híradó egység müködése közben felmerülő feladatok. További ösztönző tényező KM feladatokkal járó extra pótlék.

Hátránya: Integrálásuk kihívásokkal teli olyan probléma, aminek a leküzdésében a különleges müveleti egység ABV védelmi törzstisztjére jelentős felelősség hárul. Különleges müveleti felkészítésre van szükségük, azonban ezt követően sem lesznek képesek készségszinten végrehajtani azokat, csak jelentős mennyiségü közös kiképzést végrehajtva. Probléma az ABV védelmi katonák alacsony feltöltöttsége, amin az előnyöknél részletezett motivációs tényező segíthet.

További akadályozó tényezöként merülhet fel a képesség kialakítása során a különleges müveletekre vonatkozó egészségügyi alkalmasság vizsgálat, ami feltehetőleg csökkenti az érdeklődő jelöltek számát.

A CBRN MERT képesség kialakítása a felkészítésen túlmenően maga után vonja az alkalmazandó technikai eszközök beszerzését is annak érdekében, hogy a képességkövetelményeknek való megfelelés teljesüljön. ABV jellegü különleges müveleti képességek a szövetségi keretek között is korlátozottak, az új képesség kialakítása lehetőséget teremt egy olyan szövetségi felajánlásra, amely még hangsúlyosabbá teheti hazánk nemzetközi szerepvállalását.

A CBRN MERT alegység állománytáblája, összetétele, felszerelése nem kerül kifejtésre ebben a cikkben, azok kialakítására további egyeztetéseket követően kerülhet sor.

\section{ÖSSZEGZÉS}

Különleges műveleti kötelékek ABV támogatása kapcsán megállapítható, hogy az hagyományos hadviselést végző kötelékek ABV támogatási alapelvei alkalmazhatóak.

A minden katonára vonatkozó általános felderítési kötelezettség magában foglalja az ABV események megfigyelésével kapcsolatos jelentési kötelezettséget is.

Az osztagonként/századonként kijelölt és felkészített nem szervezetszerü ABV felderítő rajok szaktechnikai eszközökkel felszereltek, ismerik az eljárásokat és képesek azokat végrehajtani, illetve erröl jelenteni.

Az osztag/század megbízott ABV védelmi altiszt felelős a rajok alkalmazhatóságáért, alkalmazásáért és az ABV RIÉR adatokkal való feltöltéséért.

Az egység ABV törzstiszt megfelelő tapasztalattal rendelkezik a parancsnok és a törzs támogatásához, irányítja és segíti a szakmailag alárendelt osztag/század megbízott ABV védelmi altisztek szaktevékenységét, menedzseli az ABV RIÉR-t.

Speciális ABV szakfeladat esetén rövid távú szükségmegoldást jelent a Felderítést Támogató Csoport állományából egy nem szervezetszerü $A B V$ felderítő raj felkészítése, azonban ebben az esetben jellemzően az erők megóvásával kapcsolatos feladatok végrehajtására képesek csupán, továbbá $\mathrm{ABV}$ mentesítő képessége a kötelékeknek a részleges mentesítésben merül ki, a teljes mentesítést a támogatott köteléknél kell tervezni. 
Hosszú távon a CBRN MERT képesség kialakítása szünteti meg a fenti korlátozásokat, egyben lehetőséget teremt egy fajsúlyos szövetségi felajánlás megtételére.

További vizsgálatok szükségesek a század megbízott $A B V$ védelmi altisztek felkészítési idejével, a különleges műveleti kötelékek nem szervezetszerü ABV felderítő rajainak $A B V$ felderítő szaktechnikai eszközökkel való ellátásával, a CBRN MERT állománytáblájával és felszerelésével, illetve az ABV katonák különleges müveleti felkészítésével kapcsolatosan.

\section{FELHASZNÁLT IRODALOM}

[1] GERÖCS IMRE: A Magyar Honvédség különleges müveleti képesség múltja, jelene. Hadtudományi Szemle, 2012. 5. évfolyam, 1-2 szám. 293-299.o.

http://archiv.uninke.hu/downloads/kutatas/folyoiratok/hadtudomanyi_szemle/szamok/2012/2012_1/201 2_1_alt_gerocs_imre_293_299.pdf Letöltve: 2018. október 23.

[2] GRÓSZ ZOLTÁN - BEREK TAMÁS. ABV veszély elkerülésének rendszabályai, 2006. Bolyai Szemle, XVI. évf. 4. szám, ISSN: 1416-1443 http://portal.zmne.hu/download/bjkmk/bsz/bszemle2007/1/04_Berek-Grosz.pdf

[3] Ált./49. Magyar Honvédség különleges müveleti doktrína A Magyar Honvédség kiadványa 2014, MH DOFT kód: MD 3.5 (1)

[4] NATO Standardization Agency: NATO STANDARD Allied Joint Publication AJP 3.5 A v1 Allied Joint Doctrine for Special Operations 2013

[5] NATO Special Operation Headquarters, Special Operations Component Command Manual NSHQ MANUAL 80-002 2014.

[6] Atom, biológiai, vegyi védelmi doktrína $\mathrm{MH}$ Összhaderőnemi Parancsnokság kiadványa. Nyt. sz.: 237/198, MH DOFT kód: 12018

[7] BEREK TAMÁS: LCD-3 széria, mint lehetséges hatékony eszköz az alegységek ABV védelmi felszerelés rendszerében Müszaki Katonai Közlöny XXVI. évfolyam, 2016. 1. szám 68-79 p. ISSN 2063-4986 http://www.hhk.uninke.hu/downloads/kiadvanyok/mkk.uninke.hu/PDF_2016_1sz/MKK2016_1sz_ossz.pdf

[8] BEREK TAMÁS-PELLÉRDI REZSÖ: ABV (CBRN) kihivásokra adott válaszlépések az EU-ban 2011. Bolyai Szemle XX. évf. 2. szám, ISSN: 1416-1443 http://portal.zmne.hu/download/bjkmk/bsz/bszemle2011/2/Berek_Pellerdi.pdf

[9] REZSÖ PELLÉRDI - TAMÁS BEREK: Redefining the CBRN risk assessment, AARMS - Vol 8. Issue12, pp. 159-172., 2009.

[10] GWYN WINFIELD: Thunderbirds are go! http://www.cbrneworld.com/_uploads/download_magazines/Thunderbirds_are_go.pdf Letöltve: 2018. október 23. 